УДК 821.161.1 Акунін

Галич Олександр, доктор філологічних наук, професор, професор кафедри державного управління, документознавства та інформаційної діяльності Національний університет водного господарства та природокористування (м. Рівне)

\title{
ЗАВЕРШЕННЯ КВАЗІБІОГРАФІЇ ФАНДОРІНА: Б. АКУНІН «НЕ ПРОЩАЮСЯ»
}

У статті проаналізовано завершення в романі «Не прощаюся» квазібіографії Ераста Петровича Фандоріна, героя багатьох романів, повістей, оповідань Бориса Акуніна. Для иього автор розглядає твір, у якому дійовими особами є сам Фандорін, його вірний товариш Масахіро Сібата та дружина Слизавета, а також чимало інших героїв, прототипи яких $\epsilon$ пізнавані. Події відбуваються в роки громадянської війни в Росії. Окремі фрагменти роману відтворюють події на території України, зокрема в Харкові. Б. Акунін в романі «Не прощаюся», як і в низиі інших його творів, намагається видати квазібіографію Фандоріна за життепис реальної людини, що жила й творила в контексті справжніх історичних подій свого часу.

Ключові слова: квазібіографія, біографія, екстраполячія, містифікачія, детектив.

Halych A. Completion of Fandorin's quasibiography: B. Akunin «Do not say goodbye».

The article analyzes the conclusion in the novel "Do not say goodbye» to the quasibiography of Erast Petrovich Fandorin, the hero of many novels, tales, stories by Boris Akunin. For achieving this, the author considers a novel in which the actors themselves are Fandorin, his faithful companion Masahiro Sibata and his wife Elizabeth and many other heroes whose prototypes are recognizable. The events take place during the period of the Civil War in Russia. Some fragments of the novel reproduce events in Ukraine, in particular in Kharkiv. 
B. Akunin in his novel "Do not say goodbye», as in a number of his other works, is trying to represent the quasibiography of Fandorin like a biography of a real person who lived and worked in the context of true historical events of his time.

Key words: quasi biography, biography, extrapolation, mystification, detective.

Тривалі розмови про новий роман Б. Акуніна, який мав завершувати серію творів, героєм яких є дійсний статський радник, відомий детектив Ераст Петрович Фандорін, завершилися його виходом у світ 8 лютого 2018 року, рівно через двадцять років після появи першого роману про цього героя («Азазель»). У російського письменника, що зараз проживає за кордоном, вже було прощання 3 цим героєм у творі «Чорне місто», де Фандорін загинув від пострілу в голову, але в новому романі «Не прощаюся» виявилося, що він тоді залишився живим, отримавши тяжке поранення, що призвело до кількох років перебування в комі. У такому стані головний герой пережив кілька історично важливих подій світового масштабу: першу світову війну, дві російських революції, прихід до влади більшовиків, початок громадянської війни. I весь цей час поруч з ним був його вірний слуга і друг японець Масахіро Сібата, або, як його називав сам Фандорін, Maca, який допоміг героєві вижити в найскладніші періоди історії.

Метою розвідки є аналіз роману Б. Акуніна «Не прощаюся», що проливає світло на найбільший симулякр письменника, створення міфу про російську династію Фандоріних i, водночас, змальовує останні роки життя Ераста Петровича, завершуючи його квазібіографію. Студій, у яких творчість Б. Акуніна розглядалася під таким кутом зору немає. Виняток становлять праці автора цих рядків $[2 ; 3 ; 4 ; 5 ; 6 ; 7]$.

У циклі романів про Фандоріна («Азазель», «Турецький гамбіт», «Левіафан», «Смерть Ахіллеса», «Декоратор», «Особливі доручення», «Статський радник», «Коронація або останній із Романових», «Коханка смерті», «Коханець смерті», «Алмазна колісниця», «Нефритові чотки», «Увесь світ театр», «Чорне місто», «Планета вода») Б. Акунін позиціонує героя як реальну постать, що суттєво впливає на перебіг подій світової історії. Не даремно Маса, коли сусідка по купе в поїзді в останньому романі назвала 
Фандоріна щасливим тому, що той проспав важливі історичні події 1914 - 1918 рр., гнівно відреагував: «Дурепа!. Якби пан у чотирнадиятому роияі не заснув глибоко-глибоко, нічого цуього не було - ні війни, ні револющії. Він не допустив би» [1, с. 16]. Таким чином Б. Акунін робить з Фандоріна супергероя, який нібито може реально впливати на перебіг подій у світовій історії. Уже 3 роману «Чорне місто» відомо, що Ераст Петрович збирався завадити початку першої світової війни, проте лише тяжке поранення перешкодило йому це зробити. Такі неймовірні можливості персонажа розвивалися поступово, нарощуючись у кожному наступному романі циклу. Побачивши постреволюційну Росію, Фандорін приходить до висновку, що хоча б щось суттєво змінити в цій держав не може навіть він. Не даремно ноти песимізму звучать у словах, адресованих Моні: «Мені більще нічого робити в Росії. ... Я стільки років намагався якось змінити ї̈ злощуасну карму, відвести б-біду, але карму не змінив $і$ біду не відвів. Я виграв стільки боїв, а війну програв» $[1$, c. 260$]$.

У романі «Не прощаюся» Б. Акунін переконливо показує, як Ераст Петрович Фандорін поступово після коми відновлює свої надзвичайні аналітичні здібності й фізичні можливості (спершу він рухається в інвалідному візку, потім отримує змогу пересуватися самостійно). У інвалідному візку Фандорін потрапляє до анархістів, де знайомиться 3 їхнім вождем Ароном Волею, який сидів «на краю величезного полірованого столу, розмахуючи облізлим чоботом» [1, с. 57]. Його неординарна зовнішність привернула увагу Фандоріна: «Широко розставлені очі володіли дивною особливістю: їх погляд здавався розсіяним, навіть напівсонним, але при изьому вгадувався зачаєний вогонь, приглушений, але в будь-яку мить здатний спалахнути на всю потужність. Незвичайним був і відтінок блідої шкіри, майже синюватий, ніби такий, щзо ніколи не бачив сонщяя» [1, с. 59]. У надзвичайно складній ситуації, коли червоні оточили анархістів, Фандорін допомагає їхньому вождеві Арону Волі вибратися непомітно з приміщення; невдовзі останній заявить про себе у війську батька Махна в південних степах України. Однак чорна правда 
анархістів, про сутність якої головний герой дізнався в їхній штаб-квартирі в Москві, не сподобалася Фандоріну. Він навіть запитав Арона: «Ви ж людина розумна, немолода, щзо багато побачила. Невже ви у все изе вірите?» [1, с. 75]. Більшовики також не влаштовували відомого детектива. Він цілий рік під іменем брата чи отця Сергія («в залежності від того, хто до мене звертався» [1, с. 195]) провів у монастирі десь на півночі Вологодщини, очікуючи на кращі часи. Але скоро Фандоріну стало зрозумілим, що кращих часів у Росії не слід очікувати. Йому терміново довелося покинути монастир, оскільки туди прийшли більшовики й вирішили там побудувати табір для ворожих елементів. У Москві жити теж стало неможливим, бо там розгортався червоний терор. Такі обставини визначили нові плани Фандоріна на майбутнє.

У романі «Не прощаюся» Б. Акуніна його герой після року перебування в монастирі стає знову тим самим Фандоріним, яким він був до тяжкого поранення в Баку («Чорне місто»). Основні події останнього твору відбуваються в часи громадянської війни в Росії, коли Радянська влада опинилася у величезній небезпеці: Юденич веде наступ на Петроград, Корчак контролює схід, Денікін наступає на Москву. Фандоріну не подобаються ні більшовики, ні білі, яких він пов'язує зі вчорашнім днем Росії. До того ж герой раніше вже пересікався $з$ анархістами, зеленими. I жодна 3 цих політичних сил не привабила його до себе. Фандорін прагне одного, якомога швидше виїхати за кордон, назавжди покинути розірвану на шматки громадянською війною Росію, але несподіване кохання до Мони, що стала третьою дружиною героя, 3 якою він познайомився під час плавання Сіверським Дінцем, i iї вагітність затримують його. До речі, Мона - це прізвисько героїні. Ще в дитинстві їі мама, Варвара Андріївна, зважаючи на загадкову усмішку, так називала доньку («Теж щуе Мона Ліза знайшлась» [1, с. 254]). Насправді іï звуть Єлизавета. Для Акуніна Мона виявилася вже третьою дружиною i теж Слизаветою. Дві попередні його дружини також носили таке ім’я. Історія третьої дружини інтертекстуальними зв’язками пов'язана 3 романом «Турецький гамбіт», героїня якого, мама Мони, в юності виявилася закоханою в молодого 
Фандоріна. Мона з дитинства не раз чула його ім’я: «Воно звучало для неї так само, як “Ланселот”, чи “граф Монте-Крісто”, чи “Денис Давидов”» [1, с. 251]. Тобто, уже тут вигадана героїня Мона розглядає Ераста Петровича як реальну особу, чиє ім’я пов’язує як із літературними персонажами, так і зі справжніми історичними постатями. I тут же, вона, розмірковуючи про вік Фандоріна, йому за шістдесят, говорить, що це «зовсім небагато для історичної особистості» [1, с. 251]. Таким чином, для неї Ераст Петрович Фандорін $є$ реальною історичною особою.

Роман Б. Акуніна «Не прощаюся» завершує квазібіографію головного героя Ераста Петровича Фандоріна, яка розпочиналася як звичайна біографія вигаданого персонажа, але поступово набувала рис квазібіографії, тобто фальшивої біографії нібито реального героя, який, уписуючись у контекст доби кінця XIX - початку XX ст., жив поряд зі справжніми персонажами, вступав 3 ними в розмови, виконував їхні доручення, сприймався як документальна особистість, що часом суттєво впливала на перебіг історичних подій у світі. Щоправда, Б. Акунін досить вільно поводився 3 біографіями реальних історичних осіб, наближаючи їх до біографій вигаданих героїв. Для цього автору було достатньо змінити лише одну чи декілька літер у прізвищі реального героя, намагаючись цим самим зробити його художньо узагальненим. Інколи при цьому письменник міняв місцями ім'я та по-батькові героя. Скажімо, керівник «Союзу захисту офіцерів» Віктор Борисович Саввін у Б. Акуніна - це відомий у Росії терорист Борис Вікторович Савінков, керівник організованого ним «Союзу захисту батьківщини і свободи».

Частина подій роману «Не прощаюся» відбувається в Україні, Фандорін пливе на баркасі Сіверським Дінцем, пробираючись 3 території, яку контролюють більшовики, на південь до Севастополя, звідки він хотів потрапити в Свропу, але через згадані обставини герой залишається в зайнятому денікінськими військами Харкові. Там командуючий білими військами «Білий Ганнібал», генерал Володимир Зенонович Гай-Гаєвський (Б. Акунін за звичкою змінює одну літеру в прізвищі реальної особи. Насправді 
він Май-Маєвський), просить Ераста Петровича допомогти в розшуку тих, хто готував замах на головнокомандуючого збройними силами Півдня Росії генерала Антона Івановича (Денікіна, в романі його прізвище не названо), внаслідок чого загинули вихованці й вихователі дитячого будинку. Уже сам портрет Гай-Гаєвського свідчить не на його користь: «У салоні, на чолі довгого, накритого картами столу сидів літній, брезклий товстун з багряним носом, погасла цицарка в кутку рота. Під пенсне сонно поморгували маленькі припухлі оченята. Неохайний чорний мундир з полинялими погонами сидів мішком $i$ попереду був присипаний попелом, в пухлій руці дрижала склянка недопитого чаю» $[1$, с. 294].

Фандорін, взявшись за розслідування, приходить до висновку, що ті особи, які хотіли знищити керівника білої армії, знаходяться в штабі генерала Гай-Гаєвського, який зображений як п'яниця, що оточив себе сумнівними радниками. На останній зустрічі з Денікіним Фандорін звертає його увагу та той факт, що в Харкові заколот: «На чолі знаходиться офіцер для особливих доручень при командуючому Добровольчою армією полковник Скукін. Ідея полягає в тому, щзоб зробити Гай-Гаєвського військовим диктатором. Для цุього треба було зробити його головнокомандуючим щуе до взяття Москви. Сдиною перешкодою є ви. Тому Скукін $і$ його подільник військовий старшина Черепов влаштували на вас замах під час відвідин Колединського притулку. Ви вціліли чудом, але загинули діти та жінки» [1, с. 389].

Зіставляючи факти, Фандорін доводить головнокомандуючому збройними силами Півдня Росії, що в Харкові змова, і при найближчій поїздці до цього міста йому залишитися живим не має жодних шансів. Денікін приймає рішення: «Скукіна заарештувати, Гай-Гаєвського усунути від командування. Провести ретельне розслідування. Але, звичайно, не зараз, коли така напружена ситуація на фронті. Найближчим тижнем все вирішиться, $i$ тодi винуватиі понесуть кару. Поки ж не подавати виду. Не вистачало щуе в такий момент паралізувати управління Добровольчою армією» [1, с. 391]. Насправді прототип Гай-Гаєвського Май-Маєвський був усунутий від командування в 
листопаді 1919 року. Причиною стало пияцтво, постійні запої. Сюди ж додалася поразка від червоної армії під час наступу на Москву.

Роман «Не прощаюся» цікавий ще й тим, що в ньому герої в кількох епізодах намагаються пояснити етимологію псевдоніма його автора. Японське слово «акунін» можна перекласти як «негідник», «злодій», але велетенських масштабів. Вперше таке пояснення з’являється в романі «Алмазна колісниця». Чому письменник обрав псевдонім із японської мови, можна пояснити тим, що за освітою він є японістом, володіє японською мовою. Друг і слуга Фандоріна Macaxipo Сібата приніс до особливого відділу зв’язаного керівника більшовицького підпілля в Харкові Заєнка. При цьому він сказав: «Це серйозний акунін, від нього всього можна очікувати. Коли я його вже звалив $i$ взяв за горло, він укусив мене за руку» [1, с. 356]. На запитання: «Серйозний xто?» [1, с. 356], відповів: «Це довго пояснювати... Передаю цุю погану людину у ваші руки. Робіть з ним, щзо хочете» [1, с. 356]. Отож, «акунін» у тлумаченні Маси є поганою людиною. Про це свідчить і його розмова 3 Фандоріним у присутності Мони: «Коли в серпні ми шукали поганих людей, щуо закидали гранатами міську вулиц̧ю, ми щвидко вийшли на слід червоного підпілля. Але ви оголосили: ми беремо лише тих, хто винен у смерті перехожих. Ми спіймали двох акуніних, дали їм можливість чинити спротив і потім зі спокійним серцем убили» [1, с. 301]. Пізніше слово «акунін» прозвучить в устах Маси, коли він прокоментує вчинок капітана Макольцева, що пустив під укіс ешелон зі зброєю: «Справжній акунін. ... 3 чорним, але хоробрим серцемм» [1, с. 379]. Маса ж побачив пораненого капітана, і щоб привести його до тями, «натиснув під ключицею акуніна енергетичну точку. Якще людина не померла - отямиться» [1, с. 380]. Він же захотів спитати в пораненого, чому той не вбив генерала ГайГаєвського, при цьому, цінуючи героїзм противника, «вклонився акуніну» $[1$, c. 382].

Самому Фандоріну доводиться постійно стикатися 3 поганими людьми. Ще на початку роману такою поганою людиною виявився гімназист, а насправді звичайний злодій, який у поїзді обікрав сільську жінку. Набагато 
гіршим, безжальним убивцею, виявився колишній актор Громов-Невський, відомий з роману «Весь світ театр», який заради пошуку коштів на наркотики постійно йшов на тяжкі злочини, часом убиваючи зовсім невинних людей.

Про Україну як самостійну державу Фандорін дізнається від Маси: «Україна зараз окрема держава, і там теж воюють» [1, с. 35]. Арон Воля також нагадує детективу про Україну: «Я в шістнадиятому ройі сидів у камері з одним украйнцем. Зовсім простий хлопець. Нестір Махно його звали. Ми з ним багато про це (анархізм. - О. Г.) говорили. А зараз він пише мені з Украӥни. Вони там у себе створили селянську комуну і живуть по анархістській правді» [1, c. 75]. Сам же Ераст Петрович про Україну згадує в розмові з Моною під час плавання на баркасі по Сіверському Дінцю, при цьому знову виникає образ Арона Волі: «Це ідейний анархіст, адепт так званої «Чорної правди». Його звуть Арон Воля. Тепер він осів на Украӥні. У них там щось ніби анархістська республіка. Кличе подивитися власними очима» [1, с. 202]. Фандорін називає Моні місцевість в Україні, де створена анархістська республіка: «У Призов $̈$. C там таке повітове містечко, Гуляйполе» [1, с. 202]. На території України Фандорін уперше зустрічається із зеленими, що на березі Сіверського Дінця утворили «Зеленошкільну Директорію», яка виступає «проти червоних $і$ білих» [1, с. 226]. Керівником зеленої республіки був директор школи Жовтогуб. Вперше Мона побачила його таким: «На танок ... вийшла людина зовсім мирна, навіть нудної зовнішності. Був він переважно сірим: напівсиве волосся в коло, така ж борідка а-ля Чернишевський, залізні окуляри. Під мишастим піджачком виднілася сорочка навипуск з українським вишитим коміром» [1, c. 230].

Фандорін розповів Олексію Романову, що директор «мріє про союз анархістами» $[1$, с. 250], хоча на погляд головного героя «нічого з иъього не вийде. "Чорна" $і$ “зелена" правди не просто різні. Вони протилежні. Одна правда свободи, друга - правда несвободи ...» [1, с. 250].

Основні події, пов'язані з Фандоріним, відбуваються в українському Харкові, зайнятому білими військами. На прохання керівництва білою армією 
він розслідує замах на Денікіна. Під час розслідування Фандорін відновлює шифрограму, написану рукою ад’ютанта командувача білої армії капітана Макольцева: «Ростов 03.15. Александровськ - нерозбірливо. Ю...А, Юзівка 11. 30. Луганськ - нерозбірливо, ... Чугуєв 18.15» [1, с. 377]. У ній вказано графік руху військового ешелону, при цьому названі українські станції Юзівка, Луганськ, Чугуєв. Саме до Чугуєва встигає прибути Фандорін у супроводі Маси, коли Макольцев пускає під укіс цей ешелон з англійськими танками для білої армії.

Генерал Гай-Гаєвський повідомляє Фандоріну про наступ махновців на білу армію: «Махно, якого ми загнали на самий край Украйни, якимось дивом зібрав нові полчища, розметав наш заслін $і$ тепер котиться по степах на тачанках прямо на Таганрог. Він уже взяв Мелітополь і Бердянськ» [1, с. 384]. Генерал Денікін, знаючи про знайомство Фандоріна з Ароном Волею, просить детектива за посередництва останнього зустрітися з Махном, щоб переконати його зупинити наступ на білих. Для Фандоріна настає остання його пригода перед від'їздом до Криму, а далі - за кордон. Однак під час виконання цієї місії Фандорін гине, у дрезину, якою він їде за маршрутом Харків - Лозова Катеринослав, була закладена вибухівка, до чого причетний Скукін, який невдовзі після цього перебіг до червоних і пізніше став комкором. Знову ж таки, мертвого Фандоріна ніхто не бачить. Розв'язкою роману і всього циклу $є$ діалог: розмова Фандоріна і ймовірно Мони:

- Чому ти замовк? Що трапилося? - запитуєш ти.

Я замовк тому, щзо мене хтось кличе. Дуже наполегливо. Я озираюся.

- Після докажу. Треба йти. Мене звуть. Хіба ти не чуєш?

- Не чую, - говориш ти. - Я з тобою. Будь ласка!

- Ну щзо ти, - посміхаюсь я. - Зачекай тут. Я швидко. Подивися на свято, на людей. Я скоро повернуся, ти й не помітиш. Ну, не прощаюся» [1, c. 402-403].

Цікаво, що роман, як і весь цикл, написано від третьої особи, а згаданий вище діалог - від першої особи, від імені Ераста Петровича Фандоріна. Слова, 
«скоро повернуся», «не прощаюся», дають надію, всупереч заявам автора, що, можливо, читачі ще зустрінуться 3 образом неперевершеного детектива, який 3 вигаданого героя у перших романах циклу непомітно перейшов до статусу реального, здатного суттєво впливати на світ.

Романом Б. Акуніна «Не прощаюся» завершується цикл творів, які писалися два десятиліття, героєм яких є Ераст Петрович Фандорін, дійсний статський радник, детектив. За двадцять років біографія головного героя пройшла складний шлях від звичайної фікційної біографії до квазібіографії нібито реальної історичної особи. Автор роману неначе занурює свого героя, що до цього кілька років перебував у комі, у вир громадянської війни, по черзі показуючи йому ті політичні сили, що прагнуть керувати країною. Шукаючи власну правду, Фандорін не знаходить іï ні в червоних, ні в білих, ні в зелених, ні в анархістів. Саме це спонукає його покинути назавжди Росію. Проте герою здійснити свій план не вдається. Для нього залишається один шлях - загинути. Однак здається, що Ераст Петрович Фандорін ще може ожити, як це вже трапилося 3 ним в романі «Чорне місто». Адже мертвим його ніхто не бачив. Сама ж назва роману «Не прощаюся» ніби дає на це в черговий раз надію. До того ж, у Ераста Петровича є спадкоємець. Моні вдалося дістатися до Швейцарії й народити йому сина.

\section{Література}

1. Акунин Б. Не прощаюсь : Приключения Эраста Фандорина в XX веке. Часть вторая / Борис Акунин ; [худож. И. Сакуров]. - М.: Захаров, 2018. 416 с. : ил.

2. Галич О. А. «Азазель» Б. Акуніна - початок великої містифікації // Художні феномени в історії світової літератури : перехід мови в письменництво («Постколоніальні стратегії») : тези доповідей IV Міжнародної наукової конференції. - Харків: ХНУ імені В. Н. Каразіна, 2018. - С. 41-42.

3. Галич О. А. «Алтин-толобас» Б. Акуніна як роман-симулякр // Вісник Запорізького національного університету : Філол. науки. - 2016. - № 2. C. 39-44. 
4. Галич О. А. Екстраполяція постаті Фандоріна в європейську історію: «Сокіл і Ластівка» Б. Акуніна / О. Галич // Літератури світу : поетика, ментальність і духовність. - Збірн. наук. праць. - Вип. 10. - Відпов. ред. С. І. Ковпік. - Кривий Ріг, 2017. - С. 89-96.

5. Галич О. А. Початок великої містифікації: «Азазель» Б. Акуніна / О. Галич // Література світу : поетика, ментальність і духовність : Збірн. наук. праць. Вип. 11. - Кривий Ріг : ФОП Мариниченко С. В., 2018. С. 27-37.

6. Галич О. А. Створення династії Фандоріних у Росії як велика містифікація Бориса Акуніна // Літературний процес : методологія, імена, тенденції : Збірн. наук. пр. (філол. науки) / Київ. ун-т ім. Б. Грінченка ; редкол.: О. Є. Бондарева, О. В. Єременко, І. Р. Буніятова та ін. - К. : Київ. ун-т ім. Б. Грінченка, 2016. - №7. - С. 158-162.

7. Галич О. А. Функція щоденника-ніккі в детективному романі «Чорне місто» Бориса Акуніна / О. Галич // Традиційно-інноваційні стратегії сучасного художнього тексту : матеріали регіонального науково-практичного семінару. Рівне: О. Зень, 2013. - С. 79-85. 